\title{
Jamur Kontaminan Pada Umbi Kentang
}

\author{
SRI RAHAYU ${ }^{1}$, FITRI NADIFAH ${ }^{1}$, YULIANA PRASETYANINGSIH ${ }^{1}$ \\ ${ }^{1}$ Program Studi D3 Analis Kesehatan STIKES Guna Bangsa Yogyakarta \\ Jl. Ring Road Utara, Sleman, Daerah Istimewa Yogyakarta 55283 \\ email: fitri.nadifah@gmail.com
}

\begin{abstract}
Potato (Solanum tuberosum L.) is one of the five basic sources of carbohydrates. It consumed by many people world spreads. One of the constraints in potato production is the presence of fungal diseases. Fungi that cause diseases in potato crops include Phytophthora infestans which causes late blight, Fusarium oxysporum which cause fusarium wilt, Alternaria solani Sor. which cause brown spot disease, and Aspergillus niger which infect bulbs and produce aflatoxin. Identification of potatoes-contaminating fungi can lead the farmers to get a better potatoes production. This research goal is to identify potatoes-contaminating fungi in traditional market of Condong Catur, District of Sleman, Yogyakarta. This research was using descriptive method with laboratory examination. We took 30 defected potatoes suspected of being infected by fungi. Samples were taken from each potato aseptically and then cultured in Saboraud's Dextrose Agar (SDA) media. Observation was held for the fungi growth after 24 hours incubation. From the laboratory examination, there were fungal infections in all of potatoes and identified as Phytopthora infestans (26.67\%), Fusarium oxysporum (86.67\%), Alternaria solani Sor. (6.67\%), and Aspergillus niger (13.33\%). Phytophthora infestans, Fusarium oxysporum, Alternaria solani Sor., and Aspergillus niger identified as potatoescontaminating fungi in Traditional Market of Condong Catur, District of Sleman, Yogyakarta.
\end{abstract}

Keywords: contaminant, fungi, potatoes

\section{PENDAHULUAN}

Solanum tuberosum L. atau yang dikenal dengan kentang merupakan satu dari lima makanan pokok dunia sebagai sumber karbohidrat. Kelima makanan pokok tersebut adalah beras, gandum, kentang, sorgum, dan jagung. Kentang merupakan bahan komoditas pangan yang penting di Indonesia dan dibutuhkan sepanjang tahun. Secara statistik, potensi pasar kentang dapat dilihat dari analisis bank dunia tahun 1998-2010 yang memproyeksikan permintaan sayuran yang meningkat rata-rata $3,6-4 \%$ pertahun (Soegihartono, 2008).

Salah satu kendala dalam usaha produksi kentang adalah adanya penyakit-penyakit yang disebabkan oleh jamur, bakteri, dan virus. Jamur atau cendawan merupakan organisme tidak berklorofil yang hidupnya tergantung pada organisme lain, baik organisme hidup ataupun mati. Jenis jamur parasit yang sering menginfeksi tanaman kentang yaitu: Phytophtora infestans, Alternaria solani, dan Fusarium sp. (Purwantisari dkk, 2008).
Tanaman kentang dapat tumbuh di tempat yang berhawa dingin dengan kelembaban $70 \%$ sehingga memungkinkan adanya jamur yang menginfeksi. Kentang juga terkenal akan karbohidratnya yang banyak mengandung gula sakarida sehingga dapat diragikan atau difermentasikan oleh jamur (Struk, 2008).

Penyakit yang sering menyerang tanaman kentang adalah penyakit busuk daun /hawar daun yang disebabkan oleh jamur Phytophthora infestans, layu fusarium yang disebabkan oleh Fusarium oxysporum dan penyakit bercak coklat yang disebabkan oleh Alternaria solani Sor. Selain itu, terdapat pula jamur Aspergillus $s p$ yang menginfeksi umbi dan menghasilkan racun berupa Aflatoksin, Okratoksin A (OA) dan Patulin (Rahayu, 2006).

\section{METODE}

Sampel dalam penelitian ini adalah tiga puluh umbi kentang cacat yang dijual di pasar Condong Catur Yogyakarta. Kentang cacat yaitu kentang yang berpenyakit, berhama, 
bertunas, pecah, berubah warna, bermata dalam atau karena kerusakan lainnya. Kulit umbi melekuk dan agak berair dan bila dibelah, daging buah berwarna coklat.

Identifikasi jamur dilakukan dengan menanam biakan jamur pada media Saboraud's Dextrose Agar (SDA). Permukaan luar umbi kentang, yaitu bagian stolon atau mata tunas yang melekuk kedalam, ditanam pada objek glass yang sudah diberi 2 ose media SDA. Gelas benda ditutup dengan gelas penutup dan dimasukan ke dalam cawan petri yang di dalamnya terdapat kertas saring yang sudah dibasahi dengan akuades. Masingmasing cawan petri dilabeli nomor sampel dan tanggal pengujian lalu dibungkus dengan plastik. Media berisi biakan diinkubasi selama 2 hari pada suhu $20-30^{\circ} \mathrm{C}$. Setelah itu dilakukan identifikasi terhadap morfologi jamur yang tumbuh pada media.

\section{HASIL}

Sampel yang digunakan dalam penelitian adalah umbi kentang dengan kriteria kentang cacat atau berbentuk agak lonjong, dengan tekstur agak lembut berair, bermata dalam, bertunas, kulit mengelupas, dan keadaan utuh. Kondisi sampel kentang ini kemungkinan terkait dengan adanya infeksi jamur karena dari hasil identifikasi, dapat diketahui bahwa seluruh sampel kentang yang diperiksa terinfeksi oleh jamur. Dari satu sampel, dapat ditemukan lebih dari satu spesies jamur yang menginfeksi. Jamur yang ditemukan menginfeksi paling banyak pada sampel kentang adalah Fusarium oxysporum yang ditemukan pada 26 dari 30 sampel. Sedangkan jamur lain yang ditemukan adalah Phytopthora infestans, Alternaria solani dan Aspergillus niger (Tabel 1).

Spesies Fusarium oxysporum memiliki karakter hifa bersekat, konidiofor pendek, bentuk konidia bulat atau bulat telur, dan konidia tidak berwarna (Enya dkk, 2008). Jamur ini ditemukan paling banyak pada sampel kentang yang diperiksa.

Berdasarkan Struk (2008), Phytophthora infestans merupakan jamur dari kelas Oomycetes, tidak bersepta, reproduksi seksual dengan zoosporabiflagela, organ seksualnya antheridia dan oogonia. Sporangiofor biasanya tidak dibedakan dengan miselium. Sporangia berbentuk ovoid, seperti lemon, memiliki papila. Adanya papilla menjadi ciri khas Phytopthtora infestans. Koloni jamur ini berwarna ungu-pink dan berserabut.

Tabel 1. Hasil identifikasi jamur pada media SDA

\begin{tabular}{|c|c|c|c|c|}
\hline \multirow[b]{2}{*}{ Hasil } & \multicolumn{4}{|c|}{ Jamur } \\
\hline & $\begin{array}{l}\text { Phytopthora } \\
\text { infestans }\end{array}$ & $\begin{array}{l}\text { Fusarium } \\
\text { oxysporum }\end{array}$ & $\begin{array}{l}\text { Alternaria } \\
\text { solani }\end{array}$ & $\begin{array}{l}\text { Aspergillus } \\
\quad \text { niger }\end{array}$ \\
\hline $\begin{array}{c}\text { Jumlah sampel yang } \\
\text { terinfeksi }\end{array}$ & $8(26,7 \%)$ & $26(86,7 \%)$ & $2(6,7 \%)$ & $4(13,3 \%)$ \\
\hline \multicolumn{5}{|l|}{ Morfologi koloni } \\
\hline Warna & Putih & Ungu pink & $\begin{array}{c}\text { Hijau } \\
\text { kecoklatan }\end{array}$ & $\begin{array}{c}\text { Coklat } \\
\text { kehitaman }\end{array}$ \\
\hline Permukaan koloni & Seperti beludru & Berserabut & Halus & Berserabut \\
\hline \multicolumn{5}{|l|}{ Morfologi jamur } \\
\hline Hifa & Tidak bersekat & Bersekat & Bersekat & Bersekat \\
\hline Konidiofor & Tidak bercabang & Pendek & Tegak & Bercabang \\
\hline Bentuk konidia & $\begin{array}{c}\text { Firiformis, ujung } \\
\text { berpapila }\end{array}$ & $\begin{array}{c}\text { Bulat atau bulat } \\
\text { telur }\end{array}$ & Gada terbalik & Bulat \\
\hline Warna konidia & Tidak berwarna & Tidak berwarna & Coklat & Coklat Hitam \\
\hline Vesikel & Tidak ada & Tidak ada & Tidak ada & Ada \\
\hline
\end{tabular}

Jamur lain yang teridentifikasi adalah dengan ciri-ciri miselium berwarna coklat muda, konidium berbentuk seperti gada dengan konidiofor tegak, bersekat, mempunyai sekat melintang 5-10 buah dan satu atau lebih sekat membujur. Konidium mempunyai paruh 
(beak) pada ujungnya dan paruh bersekat. Menurut Idawati (2012), ciri-ciri tersebut mengarah pada spesies Alternaria solani. Jamur ini paling sedikit ditemukan, yaitu hanya pada 2 sampel.

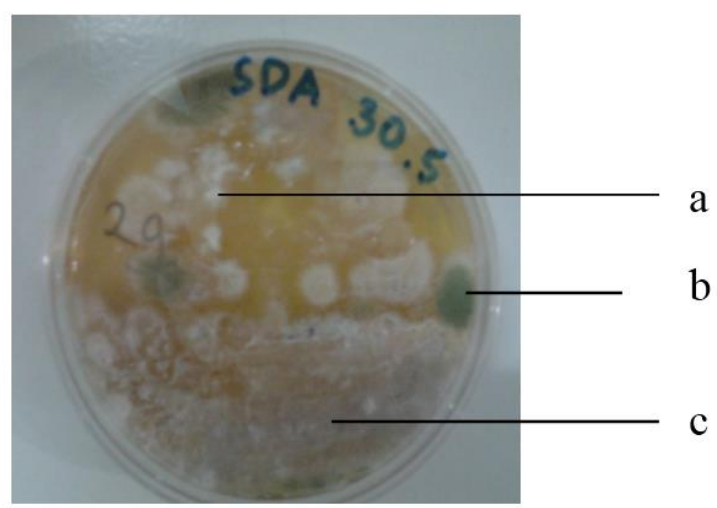

(1)

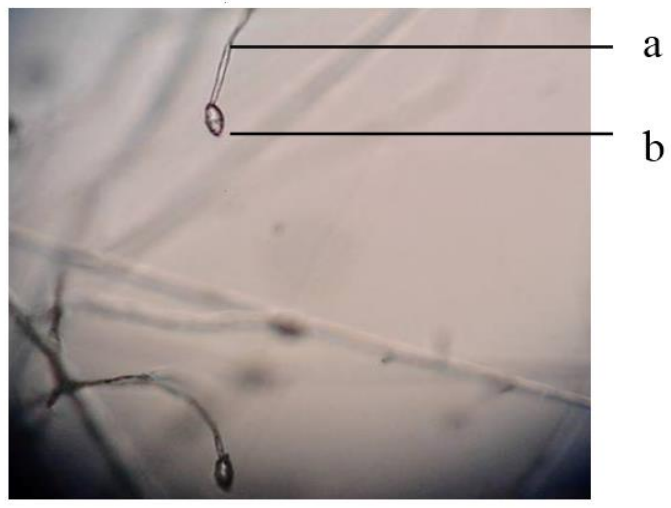

(2)

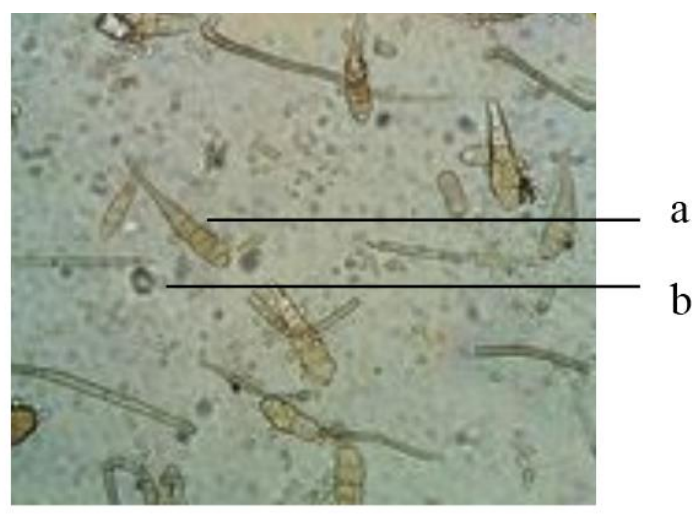

(4)
Spesies terakhir yang teridentifikasi adalah Aspergillus niger dengan karakteristik hifa bersekat, konidiofor bercabang, bentuk konidia bulat dan berwarna hitam serta terdapat vesikel (Gambar 2).
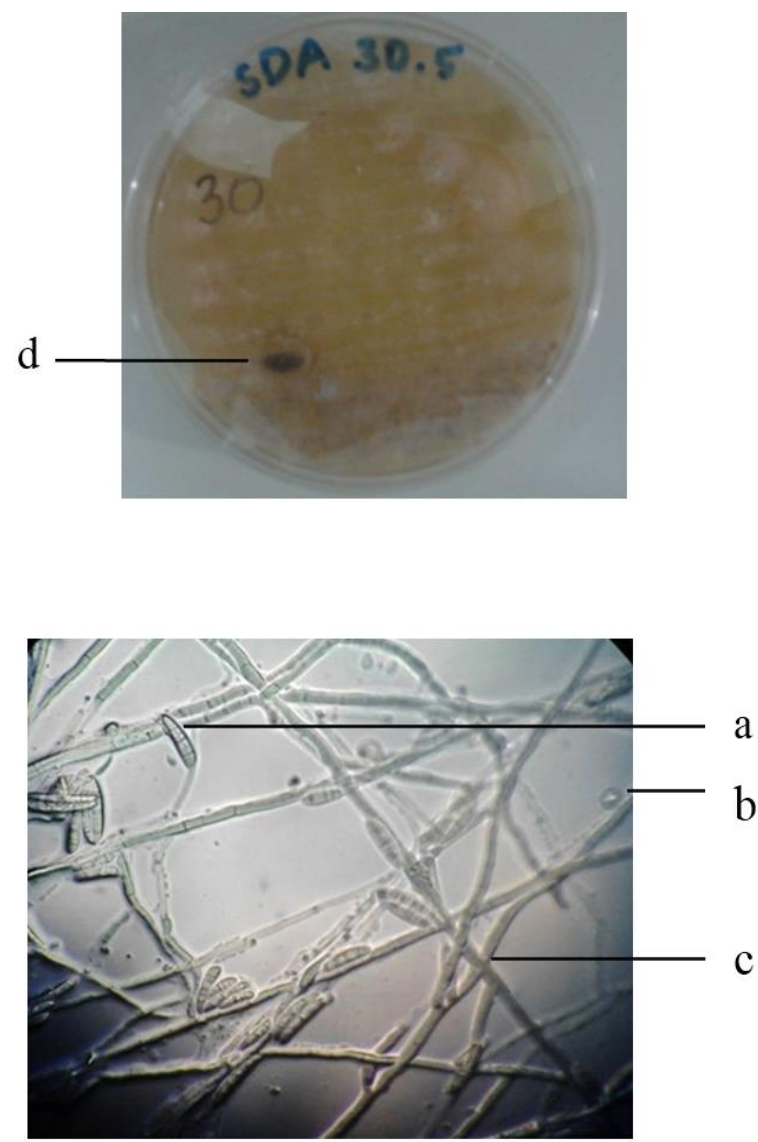

(3)

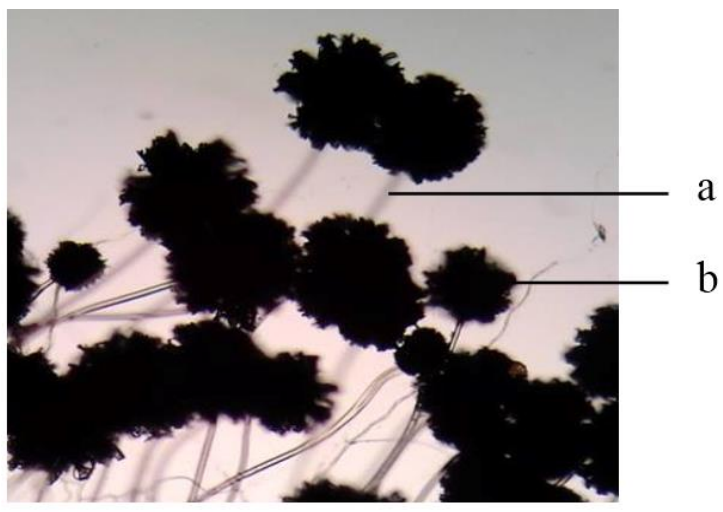

(5)

Gambar 2. (1) Koloni jamur a. Phytopthora infestans, b. Alternaria solani, c. Fusarium oxysporum, d. Aspergillus niger; (2) Jamur Phytopthora infestans: a. Hifa, b. Konidia; (3) Jamur Fusarium oxysporum a. Makrokonidia, b. Mikrokonidia, c. Hifa; (4) Jamur Alternaria solani: a. Mikrokonidia, b. Makrokonidia; (5) Jamur Aspergillus niger: a. hifa, b. konidium 


\section{PEMBAHASAN}

Faktor yang mempengaruhi tumbuhnya jamur pada umbi kentang diantaranya adalah suhu. Suhu optimum untuk pertumbuhan jamur berkisar antara $20-28^{\circ} \mathrm{C}$. Phytopthora infestans mempunyai suhu tumbuh $10-25^{\circ} \mathrm{C}$ dan suhu optimum $18-20^{\circ} \mathrm{C}$. Jamur Fusarium oxysporum mempunyai suhu tumbuh $21-33^{\circ} \mathrm{C}$ dengan suhu optimum $28^{\circ} \mathrm{C}$. Jamur Aspergillus niger tumbuh pada suhu optimum $35-37^{\circ} \mathrm{C}$, minimum $6-8^{\circ} \mathrm{C}$ dan maksimum $45-$ $57^{\circ} \mathrm{C}$. Jamur Alternaria solani Sor. mempunyai suhu tumbuh optimum $26,1^{\circ} \mathrm{C}$ dengan suhu maksimum $34,5^{\circ} \mathrm{C}$. Kelembaban adalah faktor lain yang mempengaruhi pertumbuhan jamur karena jamur hanya dapat membentuk sporangium apabila kelembaban udara lebih dari $91 \%$, dan paling baik bila kelembaban udara $100 \%$. Jamur dapat tumbuh pada kisaran $\mathrm{pH}$ 2-8,5, tetapi jamur akan tumbuh apabila pada kondisi asam atau $\mathrm{pH}$ rendah (Nelson, 2008)

Pasar Condong Catur adalah pasar seperti umumnya pasar tradisional di Indonesia, yaitu berupa bangunan atau tempat yang agak tertutup sehingga cenderung lembap dengan intensitas cahaya yang kurang dan kebersihan yang kurang terjaga. Kondisi-kondisi inilah yang memungkinkan jamur dapat berkembang biak dan menginfeksi kentang disamping terdapat kemungkinan bahwa jamur tersebut telah terinfeksi sejak awal, yaitu saat sebelum dipanen oleh petani. Menurut Ahmad (2009), jamur Alternaria dan Fusarium menyerang tanaman saat masih tumbuh sampai panen. Selain itu jamur yang menginfeksi kentang dapat berasal dari tempat penyimpanan/gudang. Tempat penyimpanan menjadi salah satu faktor kontaminasi jamur sebagai tempat yang lembab.

Menurut Zhou and Qiang (2008), Alternaria solani yang menyebabkan bercak coklat pada umbi kentang menghasilkan toksin yang juga membahayakan untuk manusia. Jamur ini menghasilkan toksin seperti asam tenuazonik, alternariol, dan alternariol metal ester. Asam tenuazonik merupakan penyebab penyakit Onyalai, sehingga menimbulkan pengaruh yang kronis dan akut (Lawley, 2006).
Selain $P$. infestans, $F$. oxysporum dan $A$. solani, ditemukan jamur Aspergillus niger pada sampel kentang. Aspergillus niger dapat mengkontaminasi biji, umbi dan meracuni makanan, karena jamur ini menghasilkan mikotoksin yaitu Aflatoksin, Okratoksin A (AO) dan Patulin. Racun alfatoxin yang dihasilkan oleh Aspergillus niger ini bersifat karsinogenik, mutagenik, teratogenik dan imunosupresif pada manusia. Pengaruh aflatoksikosis tergantung dari banyak sedikitnya aflatoksin yang masuk ke dalam tubuh bersama makanan yang mengandung aflatoksin. Aflatoksin bersifat nanpolar, tidak larut dalam air, stabil terhadap panas, tahan terhadap perlakuan fisik dan kimiawi sehingga tidak hilang dalam proses pengolahan. Pengaruh aflasitoksis pada manusia dapat bersifat akut, subakut dan kronis. Pengaruh akut maupun kronis terjadi di hati sebab organ sasaran utama toksisitas adalah hati (Villaeli, 2010).

Selain racun yang dihasilkan oleh jamur, terdapat senyawa bersifat racun yang terkandung dalam kentang yaitu solanin. Senyawa ini dapat tumbuh secara alami pada bagian tumbuhan manapun termasuk daun, buah dan umbi. Kentang yang mengandung zat ini diindikasikan berwarna hijau. Gejala keracunan biasanya muncul $8-12$ jam setelah menyantap kentang yang bernoda hijau, berupa rasa terbakar di mulut, sakit perut, mual, muntah, diare, sulit bernafas, gangguan detak jantung dan sakit kepala. Cara terbaik adalah menghindari memilih kentang yang bernoda hijau, banyak matanya dan bertunas. Jika terlanjur membeli kentang bernoda hijau, buang noda hijau, lalu rendam kentang dalam larutan air yang telah dicampur garam sebelum diolah ataupun dengan cara menyimpan kentang di tempat yang sejuk, kering dan gelap. Hindari menyimpan kentang di tempat yang terpapar sinar matahari atau cahaya karena dapat menyebabkan terbentuknya solanin (Soegihartono, 2008).

Kentang segar yang baik untuk dikonsumsi adalah kentang dalam keadaan utuh, bersih dan segar yang didukung dengan keseragaman warna kulit, bentuk, ukuran. Sedangkan ciri kentang yang terinfeksi 
penyakit biasanya memiliki banyak bercak berwarna, bertunas, berubah warna, kulit mengelupas, bermata dalam atau karena kerusakan lainnya. Selain itu, kulit umbi kentang melekuk, agak berair dan bila dibelah, daging umbi berwarna coklat.

\section{KESIMPULAN}

Jamur kontaminan yang ditemukan paling banyak adalah Fusarium oxysporum yang teridentifikasi pada 26 dari 30 sampel. Jamur lainnya yang teridentifikasi meliputi pasar yang meliputi suhu, kelembapan dan intensitas cahaya. Untuk menghindari efek dari kontaminasi jamur pada sampel, penjual disarankan untuk menyimpan kentang pada lingkungan yang dapat mencegah tumbuhnya jamur, sedangkan pembeli disarankan untuk dapat memilih kentang yang baik dan tidak menunjukkan ciri-ciri cacat Phytophtora infestans, Alternaria solani dan Aspergillus niger. Faktor yang memungkinkan tumbuhnya jamur adalah infeksi saat masa tanam hingga panen dan kondisi lingkungan.

\section{DAFTAR PUSTAKA}

Ahmad RZ. 2009. Cemaran Kapang Pada Pakan dan Pengendaliannya. Jurnal Penelitian dan Pengembangan Pertanian. vol 28 (1): 15-22.

Enya J, Togawa M, Takeuchi T, Yoshida S, Tsushima S, Arie T, and Sakai T. 2008. Biological and Phylogenetic Characterization of Fusarium oxysporum Complex, Which Causes Yellows on Brassica spp., and Proposal of $F$. oxysporum f. sp. rapae, a Novel Forma Specialis Pathogenic on B. rapa in Japan. Phytopathology. vol 98 (4): 475-83.
Idawati N. 2012. Pedoman Lengkap Bertanam Kentang. Yogyakarta: Pustaka Baru Press. hal 83-97.

Lawley R. 2006. Altenaria Toxins. www. mycotoxins.com. Diakses pada Januari 2015

Nelson SC. 2008. Late Blight of Tomato (Phytophthora infestans). Plant Diseases. vol 45:2

Purwantisari S, Ferniah RS dan Raharjo B. 2008. Pengendalian Hayati Penyakit Lodoh (Busuk Umbi Kentang) Dengan Agens Hayati Jamur-Jamur Antagonis Isolat Lokal. BIOMA. vol 10 (2): 13-19.

Rahayu WP. 2006. Mikotoksin dan Mikotoksis: Mikrobiologi keamanan pangan Departemen Ilmu dan Teknologi Pangan. Bogor: Institut Pertanian Bogor. hal 256-257.

Soegihartono C. 2008. Kajian Kepuasan Petani Dalam Penggunaan Benih Kentang Tidak Bersertifikat di Kota Batu Propinsi Jawa Timur. http://www.dikti.org. Diakses pada Januari 2015.

Struk PC. 2008. Preface to a Spesial Issue on Late Blight and Genetic Modification. Potato Res. vol 51:1-3. DOI 10.1007/s111540-008-9096-z.

Villaeli A. 2010. Ragam Aflatoksin sebagai Salah Satu Cemaran Alamiah Bahan Pangan. Departement of Chemistry. Yogyakarta: University Negeri Yogyakarta.

Zhou B and Qiang S. 2008. Environmental, Genetic and Cellular Toxicity of Tenuazonic Acid Isolated from Alternata. African Journal, Biotechnol. vol 7(8): 1151- 1156. 